\title{
Conditions of production and the differenciation of the peasantry in rice economies
}

\section{Francesca Bray}

\section{(2) OpenEdition \\ 1 Journals}

Electronic version

URL: https://journals.openedition.org/tc/815

DOI: $10.4000 /$ tc. 815

ISSN: 1952-420X

Publisher

Éditions de l'EHESS

Printed version

Date of publication: 1 October 1988

ISSN: 0248-6016

Electronic reference

Francesca Bray, "Conditions of production and the differenciation of the peasantry in rice economies", Techniques \& Culture [Online], 11 | 1988, Online since 16 January 2006, connection on 29 September 2022. URL: http://journals.openedition.org/tc/815 ; DOI: https://doi.org/10.4000/tc.815

This text was automatically generated on 29 September 2022

All rights reserved 
Conditions of production and the differenciation of the peasantry in rice economies

Francesca Bray 